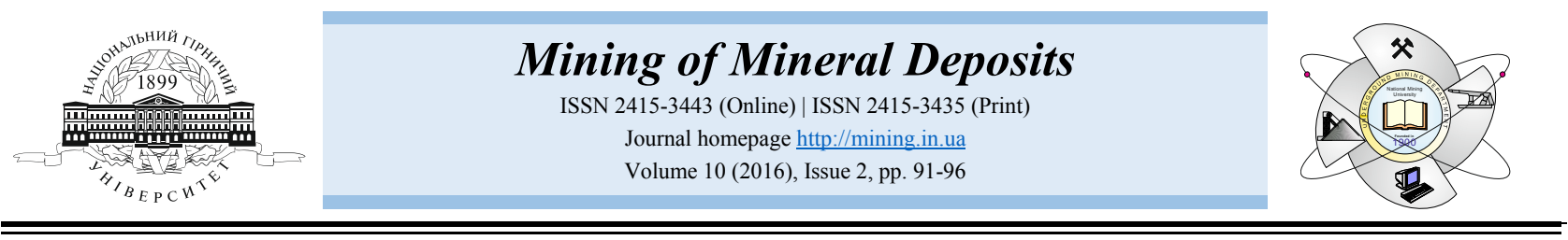

\title{
APPLICATION OF SHOCK BLASTING MODE IN MINE ROADWAY CONSTRUCTION
}

\author{
S. Mineev ${ }^{1 *}$, O. Yanzhula ${ }^{2}$, O. Hulai $^{2}$, O. Minieiev ${ }^{3}$, V. Zabolotnikova ${ }^{4}$ \\ ${ }^{1}$ Department of Dynamic Phenomena Management of Rock Pressure, Institute of Geotechnical Mechanics named after M.S. Polyakov \\ of the National Academy of Sciences of Ukraine, Dnipropetrovsk, Ukraine \\ ${ }^{2}$ MA "Pokrovske", Krasnoarmiisk, Ukraine \\ ${ }^{3}$ Department of System Analysis and Control, National Mining University, Dnipropetrovsk, Ukraine \\ ${ }^{4}$ Department of Foreign Languages, National Mining University, Dnipropetrovsk, Ukraine \\ *Corresponding author: e-mail sergmineeV@gmail.com, tel. +380503634258
}

\section{ЗАСТОСУВАННЯ РЕЖИМУ СТРУШУВАЛЬНОГО ПІДРИВАННЯ ПРИ ПРОВЕДЕННІ ГІРНИЧИХ ВИРОБОК}

\author{
С. Мінєєв ${ }^{1 *}$, О. Янжула ${ }^{1}$, О. Гулай ${ }^{1}$, О. Мінєєв ${ }^{2}$, В.Заболотнікова ${ }^{4}$ \\ ${ }^{I}$ Відділ управління динамічними проявами гірського тиску, Інститут геотехнічної механіки ім. М.С. Полякова НАН України, \\ Дніпропетровськ, Україна \\ ${ }^{2}$ Шахтоуправління “Покровське”, Красноармійськ, Украӥна \\ ${ }^{3}$ Кафедра системного аналізу та управління, Національний гірничий університет, Дніпропетровськ, Україна \\ ${ }^{4}$ Кафедра іноземних мов, Національний гірничий університет, Дніпропетровськ, Украӥна \\ *Biдповідальний автор: e-mail sergmineeV@gmail.com, тел. +380503634258
}

\begin{abstract}
Purpose. Working out measures providing safe application of a shock blasting mode while driving workings in outburst-prone coal seams.

Methods. Conveying of shock blasting at the mine workings on the coal mines of Ukraine is regulated by a number of specification documents. At the same time, in the process of shock blasting production numerous technological violations of the mode take place and there are often gas-dynamic phenomena, including those with death of people. The mode of shock blasting at mines is used for unworked coal breaking on outburst-prone seams regardless of results of prognosis and efficiency of antilanding measures done, at troublesome seams in the zones where the reading "prone" is set by latest estimate; and while driving in outburst-prone coal seams.

Findings. Shock blasting is used at mines at mines in rather wide range of mining and geological conditions. It is recommended to apply the methods of intensity and frequency of gas and oil emissions attenuation at shock blasting on especially outburst-prone layers. The methods of depth increase of pre-face part of a coal bed unloading zone are used. The increase is achieved by means of heading rock loosening of adjacent strata, advanced blasting, blast hole charge operation in adjacent strata, front-rank loosening (camouflet blasting) of coal bed. Moreover, the blasting pattern with formation of piled blocking retaining wall is applied.
\end{abstract}

Originality. The main scientific and technical principles of the safe and efficient use of a shock blasting mode in blast hole drilling driving in outburst-prone coal seams and beds are formulated.

Practical implications. Applying shock blasting mode in mine workings conveying proved to be one of the safest methods to prevent gas-dynamic phenomena. Simultaneously, as a rule, this method is one of the most costinefficient methods especially when paced work of coalmine is vital. Therefore, basic research directions are to be continued towards reduction of expenses and increase of this method application efficiency.

Keywords: shock blasting, mode, working driving, outburst-prone seam, mine safety

\section{INTRODUCTION}

Using the shock blasting mode in mining proved to be one of the safest methods to prevent gas-dynamic phenomena. Simultaneously, as a rule, this method belongs to the most cost-inefficient ones especially when paced work of coal mine is vital. Therefore, basic research directions are to be continued towards reduction of expenses and increase of this method application efficiency ( $\mathrm{Pi} \&$ Hoogstrate, 2016). 


\subsection{The problem and its connection with scientific and practical tasks}

The conveying of shock blasting in mining at the coal mines of Ukraine is regulated by a number of regulatory documents: "Instruction on application of shock blasting at the coal mines of Ukraine", "Unified safety regulations for shooting works", "Mine safety regulations on layers inclined on the gas-dynamic phenomena" and currently operating "Safety rules in coal and slate mines". Along with that at shock blasting conveying, a lot of the technological mode violations take place and quite often there are the gas-dynamic phenomena (Lanari \& Fakhimi, 2015), including those with the death of people.

\subsection{Analysis of researches and publications}

The basic terms used in the practice of blasting are preliminary considered in the articles (Zhang, 2016; Zhu, Zhu, Jia \& Song, 2014).

Shock blasting is a blasting conducted in the certain mode, aimed at protecting people against the consequences of coal, rock and gas outbursts at the seams prone on sudden gas and coal outburst as well as at outburst-prone strata.

A dangerous area at shock blasting means all mining workings located along the path of an outgoing vent air current from the blast area as well as all the workings with the intake ventilation current which in some cases of ventilation faulting or vent current inversion can be covered by mined rock or loaded with methane as a result of a coal, rock and gas outburst possible at shock blasting (Ramulu \& Rao, 2012).

A control station of shock blasting conveying is a place where the performing authority of shock blasting from the surface of mine is to stay, where all the information about the works conducted underground comes in, on the basis of which the decisions are made and out orders on further works conducting are given out.

An indoor station of shock blasting conveying is a special place of refuge from which the blasting in one or many coalfaces is produced. In the case of an indoor station absence, the place of shot firer refuge is used for blasting.

Permanent firing line is a special shot firing cable laid from a coalface to the place of a shot firer refuge.

The announcement about the time of shock blasting conveying in definite coalfaces is put on a bulletin board, in a lamp room and at shafts, in the openings with return ventilation air which are used for persons in bye conveying.

Baring of layers, apt to the instantaneous outbursts of coal and gas is a workpackage on approaching, baring, intersecting and moving away from the indicated layer apt to the gas-dynamic phenomena.

The two tier deck charges are blasthole charges of explosives divided by stemming of certain length into two parts (tiers) and initiated by short delay blasting caps so that the tier closer to the hole mouth or hole collar detonates first. A plug is a stemming made of clay, mixture of clay with sand or polyethylene capsules with water in combination with locking clay stemming, placed between the deck charges.

Ingibitory stemming is a stemming made of materials the aerosols of which create or strengthen a preventive environment in a face space at dispersion. A water-spray curtain is an aquatic curtain created in a mine face space at explosive works by dispersion of water from properly located fragile plastic vessels destroyed by the explosion of a preventive explosive placed in each of them, initiated by preventive instantaneous electric blasting caps.

A water-air curtain of the protracted action is a curtain with the set time of continuous action, created by means of mechanical sprayers of water in a working in the blasting area (in a 4 to $5 \mathrm{~m}$ distance from the coalface to be blasted). Aerosol (powder-like) curtains are the preventive environment created in a coal face space at blasting works by means of explosive dispersion of powder-like inhibitor from properly located fragile polyethylene vessels (packages).

Methods of decline of coal and gas outbursts intensity and frequency are the special blasting pattern in the development workings and rooms providing creation of effective artificial (additional) seam discharge area in front of a working face by means of explosive charge blasting in an unworked face as well as with the use of patterns of working driving with the charge blasting of a rock face, or coal and gas charging isolation by explosive erection of bulk blocking stopping from blasted rock.

\subsection{Problem statement}

Squall at coal mines is used to break unworked coal of outburst-prone seams regardless of forecasting and efficiency results and outburst prevention measures done, at troublesome seams in the zones where the reading "prone" is set by latest estimate; and while driving on outburst-prone coal seams. The main requirements and rules as well as technologies of production and safe working conditions organization while conveying shock blasting in mining at outburst-prone seams.

\section{MATERIAL STATEMENT AND RESULTS}

It should be mentioned that shock blasting at mines is used for uncovering outburst-prone coal seams and sheds with the thickness more than $0.1 \mathrm{~m}$ prognosis and efficiency of outburst prevention measures done, at in the zones where the reading "prone" is set by latest estimate; and while driving in outburst-prone coal; uncovering troublesome seams and sheds if dangerous values of outburst hazard factors have been forecast or there was no forecast done before uncovering; uncovering sandstone at the depth $600 \mathrm{~m}$ and more if its outburst hazard has been forecast or there was no forecast done before uncovering; driving workings in outburst-prone sandstone if dangerous values of outburst hazard factors have been forecast or there was no forecast done before uncovering; driving horizontal workings, inclined drifts and upraise drifts with the angle of hade up to $10^{\circ}$ inclusively; in the rooms in flat and steep seams; in the shield faces, in mounting coal heading of shield faces and long-wall stables of steeply inclined and inclined seams; at camouflet blasting; at embedded and out of seam torpedoing which has been performed to reduce gas-dynamic activity of coal seam (Mineev, 2016; Ishchenko et al., 2000).

For the first time shock blasting was applied in 1890 in France, in home practice - in 1917 at the mine "Krasnyi Profintern" (Yenakiievo) at dissection of "Deresovka" seam at the $340 \mathrm{~m}$ horizon. It was accompanied by the 
coal and gas outburst with intensity of $200 \mathrm{t}$ (Shevtsov, 2003).Working areas and blind drifts where shock blasting is applied should be equipped by the AKM utensils, and the workers directed for the production of shock blasting should be equipped with firedamp alarms combined with head lamps.

The parameters of the mode of a shock blasting for driving outburst-prone seams and seams being threatened should provide complete breaking of coal on all driving sections. Thus, if at shock blasting the configuration of coalface required by a shock blasting mode is not achieved it is necessary to produce reblasting on coalface road head outlining. It is thus necessary to keep in view that it is categorically prohibited to design the face after shock blasting by any machines, mechanisms or hand instrument. The driving where shock blasting is to be conducted before explosive works should be freed on not less than $100 \mathrm{~m}$ extent of a coalface from trolleys and other equipment encumbering it on more than one-third of its cross-section. It is especially important, that before shock blasting vent devices located within the limits of a dangerous area, and also the bridges set for prevention of gas penetration onto other areas or mine horizons were examined by the technical inspection representatives.

Shock blasting is conducted either during a special shift or during special intershift interruptions or at the beginning or end of a shift. The time necessary for blasting is determined on the basis of time-study data and it should be approved by the order of a mine manager. For every coalface a dangerous area should be preliminary determined, which includes all drivings located along the outgoing vent stream from the place of explosion, as well as drivings with the acting fresh stream of air that can get gassy during possible realization of the gasdynamic phenomenon. During shock blasting the presence of people in a dangerous area, as well as simultaneous work of another shift is forbidden. In the case of the stratal and out of the seam torpedoing production necessity it is assumed to produce it during a special technological shift or weekend.

In addition, for every particular coalface before shock blasting "Instruction on application of shock blasting at the coal face" is designed. It establishes the order and technology of shock blasting production for particular mining conditions and blasting pattern. Instruction on application of shock blasting at the coal face is component part of a chart of outburst-prone seams and seams being threatened dissection, charts of underground driving and lining, charts of workings and working areas. The order of shock blasting production and persons accountable for its implementation are approved by the order on a mine.

The order specifies the responsible performing authority of shock blasting preparation and conduction from the surface of mine - he is the performing authority of shock blasting in the working face; the person responsible for the watch posts setting on a dangerous area and for the people getting out of this zone; the person accountable for the conduction of shock blasting in a coalface; shotfirers assigned to particular coalfaces; the person, accountable for control of the coalface ventilation state, vent devices, stone dust barriers and and water barriers; the person, responsible for disconnecting of electric power in a workings in a dangerous area; the person accountable for the work mode of lifting equipment in the time of shock blasting production. The order lists as well the names of responsible persons and masters-shotfirers who will execute the work prescribed during of all the time of a shock blasting. Particular persons from this list, taking part in shock blasting works actively in particular faces and shifts are recorded in a special "Log book of shock blasting at a mine" and special task sheet. In addition, it is necessary to keep in view that an engineer-in - chief or his deputies should be the performing authority of shock blasting conduction from the surface of mine at the following cases - baring and crossing by openings outburst-prone seams and seams being threatened, and also crossing by other workings outburst prone areas (active geological violations, zones of rock pressure, complicated by geological violations, mining works sites). It is assumed to lay the supervision at the shock blasting production from the surface of mine on a shiftman or an overman in other cases at approaching and moving away of the working, in drifts, crossholes, lavas, field making, barrels of and other. In addition, the responsible authority for shock blasting in a coalface should be a technical worker of a division where blasting is to be conducted, not lower than the deputy or assistant of an overman.

To the beginning of the time distinguished for the shock blasting production all people must be taken out from a dangerous area. Admitting o people to this zone after shock blasting production is allowed after measuring of methane level, verification of coalfaces and equipment, removal of watchposts and reporting of the performing authority of shock blasting conduction in coalfaces to the authority of shock blasting conduction from the surface of mine. The last one, on the basis of the report and telemetric data of AHK system, issues permission on people admitting to the working. In the case of realization of the gas-dynamic phenomena admitting people to the dangerous area is possible only according to written permission of a responsible person after emergency elimination.

Before the beginning of charging-up in all the workings of a mine, located within the limits of dangerous area, the electric power must be switched off. Electric power switching on is assumed only after the control of methane level in the working atmosphere and checking the integrity of electrical equipment and cables after an exposing and provoked gas and dynamic phenomenon. However, disconnecting of ventilators of local ventilation, telephone connection and means of methane level automatic control, as well as sensors used for control of coal beds outburst hazard is prohibited during shock blasting production. In the coalfaces of workings where in connection with a flood potency it is impossible to disconnect electric power before the charging-up deenergizing is fulfilled before the beginning of explosive network mounting. In the deepened barrels, disconnecting of electric power from the lifting equipment is produced after departure of people from the shaft.

All reports of explosive works performers in the underground working about preparation of coal face to the explosing, watch posts setting, moving away ofworkers to a safe place, permission on an explosing and examina- 
tion of coalface after an explosing, permission on admittance of workers and other official conversations must be recorded by an authority of shock blasting conduction from the surface of mine on the electronic carrier and saved not less than 3 days. Examining coalface after explosing is conducted only with the permission given by the authority of shock blasting from the surface of mine after getting him data from the AKM system on methane level in the working where the explosing was conducted but not earlier than in 30 minutes after an explosing and at methane level less than $2 \%$. A person responsible for shock blasting in a coalface and a shot firer must conduct inspection of a coalface.

A person responsible for shock blasting measuring methane level at moving toward a coalface for its examination after a shake explosion, must be in the distance not less than a $3 \mathrm{~m}$ ahead of ashotfirer. At finding out the methane concentration $2 \%$ and more they are obliged to immediately go back into the working with the fresh stream of air and to report about it to the authority of shock blasting conduction from the surface of mine .To prevent self-ignition of methane-air and methane-dust-air mixtures at a shock blasting, apart from the observance of the gas and dust regulations, it is recommended to apply: the water-spray, air or aerosol (powder-like) curtains created by dispersion of water or flame-retardant powder; measures on charges burning down prevention; water stemming or pasteous ingibitory stemming.

Initiation of charges in shock blasting should be produced by preventive EBS of instantaneous and shortdelay action in course of time of deceleration of the last stage at not less than $220 \mathrm{msec}$. At dissection of layers before their baring EBS of short-delay action whis the timing of the last stage not longer than $320 \mathrm{msec}$ can be used. Explosing of charges must be produced in a full face by explosive devices permitted by the mine savety authorities for this aim which can blast up the complete set of charges in full face (Mineev, 2016).

A place of a shotfirer shelter must be in the distance not less than $600 \mathrm{~m}$ from a coalface, but not nearer than $200 \mathrm{~m}$ from the place of confluence of return ventilation air with a fresh intake air, and people who are not involved into blasting production should be $\mathrm{t}$ be on a fresh stream at the distance not less than a $1000 \mathrm{~m}$ against intake air motion direction. In coalfaces, where the early coal getting has been done and explosive works are produced only in rock. A place of a shotfirer shelter must be in the distance not less than $200 \mathrm{~m}$ from the confluence of a working driven and a working ventilated due to mine ventilation pressure drop against intake air motion direction

At driving preparatory workings in coalfaces shock blasting can be used both in coal or simultaneously in coal and rock and in adjacent strata during driving of the horizontal, loping and rising workings with the angle of slope up to $10^{\circ}$ inclusively. It is necessary to keep in view that in the coalfaces of working where the early getting of coal is produced, advancing of a coalface concerning blast hole ends of a stope in rock should be not less than a $0.5 \mathrm{~m}$. When this value is less explosive works in adjacent strata should be conducted in the mode of shock blasting.

In the places of geological violations blasting in coal and rock should be produced simultaneously. Loading and explosing of charges of every cycle, including the cases of a separate explosion in coal and rock is permitted to produce after ventilation of coalface, measuring of methane level, blasted rock mucking, performing safety measures in a coalface and adherent workings in not less than $20 \mathrm{~m}$ distance. However, in all cases a depth of stope on coal must be not more than $2 \mathrm{~m}$. At a separate explosing in the mixed coalfaces the explosing of charges on coal and rock must be produced at different times.

\section{CONCLUSIONS}

Shock blasting in the faces of developing openings in steep seams and rush-prone seams should be produced either with the use of an advance support preliminary setting or rock wall breaking or additional support of unworked coal. It is recommended to apply the methods of intensity and frequency of gas and oil emissions attenuation at shock blasting on especially outburst-prone layers.

The methods of depth increase of pre-face part of a coal bed unloading zone are used to reduce intensity and frequency of gas and oil emissions attenuation at shock blasting on especially outburst-prone layers. The depth increase of pre-face part of a coal bed unloading zone is fulfilled by means of heading rock loosening of adjacent strata, advanced blasting, blast hole charge operation in adjacent strata, front-rank loosening (camouflet blasting) of a coal bed. Moreover the blasting pattern with formation of piled blocking retaining wall is applied. The increase of the unloading zone of a coal bed pre-face part is achieved by means of advance shotholing of a coal bed or adjacent strata and advance waterblasting. The most important of these methods are described below.

Heading rock loosening of adjacent strata is supposed to be used while driving developing openings by means of a mixed face on especially outburst - prone seams, in geological violations zones, increased gas pressure zones, support pressure zones by means of simultaneous blasting of blastholes for heading rock loosening of adjacent strata and breaking coal and rock in a driving with the blastholes for heading rock loosening being blasted in advance.

The method of advanced blasting can be used in mixed faces only at simultaneous breaking of coal and rock by blasting explosives in extended blastholes with an ordinary water stemming or advance water stemming put in the bottom end. Capsules with the size equal to an extended part of borehole are used for advance water stemming.the capsule diameter should be $1-2 \mathrm{~mm}$ larger than the borehole diamer. Filling the capsule with water is done after putting it into a borehole bottom end by special extender. Standard polyethylene capsules can be used for advance water stemming in inclined holes. After filling capsules with water and putting them into a bottom end holes are covered with water.

The method of bore hole charge blasting in adjacent strata is used at driving openings in the seams with the thickness not less than $1 \mathrm{~m}$. While driving steep seams and rush-prone seams the depth of pull should be not more than $1.1-1.3 \mathrm{~m}$ and the charge weight of boreholes at the contact with the coal seam should be not more than $0.6 \mathrm{~kg}$ at driving rush-resistant seams the depth of pull should be taken according to technological conditions.

Piled blocking retaining wall consists of a mined rock which is broken with delay after coal breaking. It prevents an outburst provoked by blasting. 
The method of front-rank loosening (camouflet blasting) of coal bed is recommended to reduce frequency and intensity of outbursts in shield faces of steep seams especially at conjunction with a ventilation shaft.

As can be stated in accordance with the research done using the shock blasting mode in mining proved to be one of the safest methods to prevent gas-dynamic phenomena. Simultaneously, as a rule, this method is one of the most cost-inefficient methods especially when the paced work of coal mine is vital. Therefore, basic research directions are to be continued towards reduction of expenses and increase of this method application efficiency.

\section{ACKNOWLEDGEMENTS}

The authors express their gratitude to the staff of the, Institute of Geotechnical Mechanics named after M.S. Polyakov of the National Academy of Sciences of Ukraine, for their support and assistance during research conducted at the Institute.

\section{REFERENCES}

Ishchenko, K., Kratkovskiy, I., Konoval, S., Konoval, V., Mazur, A., \& Nasheda, V. (2016). Efficiency of blasting of rocks with complex structure by multicharges in non-metallic pits. Metallurgical and mining industry, (1), 191-197.
Lanari, M., \& Fakhimi, A. (2015). Numerical study of contributions of shock wave and gas penetration toward induced rock damage during blasting. Computational Particle Mechanics, 2(2), 197-208. http://dx.doi.org/10.1007/s40571-015-0053-8

Mineev, S. (2016). Spopoby prognoza $i$ bor'by s gazodinamicheskimi yavleniyami na shakhtakh Ukrainy. Dnipropetrovsk: Skhidnyi vydavnychyi dim.

Pi, V.N., \& Hoogstrate, A.M. (2007). Cost optimization of abrasive blasting systems: a new and effective way for using blasting nozzles. Key Engineering Materials, (329), 323-328.

http://dx.doi.org/10.4028/www.scientific.net/kem.329.323

Ramulu, M., \& Rao, K. (2012). Novel blasting techniques for productivity improvement in hard rock underground dolostone mine. Blasting in Mining - New Trends, 61-67. http://dx.doi.org/10.1201/b13739-8

Shevtsov, N. (2003). Razrushenie gornykh porod vzryvom. Donetsk: DonNTU.

Zhang, Z. (2016). Rock Blasting in Underground Mining. Rock Fracture and Blasting, 373-392. http://dx.doi.org/10.1016/b978-0-12-802688-5.00019-1

Zhu, H., Zhu, S., Jia, G., \& Song, Z. (2014). Numerical simulation of blasting effects on soft coal under different confining pressure. Progress in Mine Safety Science and Engineering II, 997-1002. http://dx.doi.org/10.1201/b16606-188

\section{ABSTRACT (IN UKRAINIAN)}

Мета. Розробка заходів щодо безпечного застосування режиму хитного підривання при проведенні виробок по викидонебезпечних вугільних пластах.

Методика. Проведення струшувального підривання при проведенні гірничих робіт на вугільних шахтах України регламентується цілим рядом нормативних документів. Разом 3 цим, при проведенні струшувального підривання має місце багато технологічних порушень режиму й нерідко відбуваються газодинамічні явища, у тому числі з людськими жертвами. Режим струшувального підривання на шахтах застосовується для руйнування вугільного масиву на викидонебезпечних пластах незалежно від результатів прогнозу та ефективності, виконаних противикидних заходів; на загрозливих пластах в зонах, де поточним прогнозом встановлені значення “небезпечно”; при проведенні виробок по викидонебезпечних вугільних пластах.

Результати. Струшувальне підривання застосовується в шахтах при різних гірничо-геологічних умовах. На особливо викидонебезпечних пластах при проведенні струшувального підривання рекомендується застосовувати способи зниження інтенсивності та частоти викидів вугілля й газу. Використовується методи збільшення глибини зони розвантаження привибійної частини вугільного пласта, яка досягається у шахтних умовах за рахунок застосування способів передового розпушування вмішуючих порід, випереджаючого підривання, підривання шпурових зарядів у вміщуючих породах, передового розпушування (камуфлетного підривання) вугільного масиву. Крім того, застосовується паспорт БВР з утворенням насипної перегороджуючої перемички.

Наукова новизна. Сформульовано основні науково-технічні принципи безпечного та ефективного використання режиму струшувального підривання при виконанні буропідривних робіт на викидонебезпечних вугільних пластах і породах.

Практична значимість. Як встановлено, використання режиму струшувального підривання при веденні гірничих робіт є одним з найбезпечніших способів боротьби із газодинамічними явищами, але одночасно він $\epsilon$, як правило, одним з найбільш економічно витратних, особливо при необхідності ритмічної роботи вугільної шахти, тому основні напрямки досліджень повинні бути продовжені у напрямку зменшення витрат і підвищення ефективності застосування даного способу.

Ключові слова: струшувальне підривання, режим, проведення виробок, викидонебезпечний пласт, безпека робіт

\section{ABSTRACT (IN RUSSIAN)}

Цель. Разработка мероприятий по безопасному применению режима сотрясательного взрывания при проведении выработок по выбросоопасным угольным пластам.

Методика. Производство сотрясательного взывания при ведении горных работ на угольных шахтах Украины регламентируется целым рядом нормативных документов. Вместе с этим, при производстве сотрясательного взрывания имеет место много технологических нарушений режима и нередко происходят газодинамические явления, в том числе с человеческими жертвам. Режим сотрясательного взрывания на шахтах применяется для отбойки угольного массива на выбросоопасных пластах независимо от результатов прогноза и эффективности, 
выполненных противовыбросных мероприятий; на угрожаемых пластах в зонах, где текущим прогнозом установлены значения “опасно”; при проведении выработок по выбросоопасным угольным пластам.

Результаты. Сотрясательное взрывание применяется в шахтах при весьма широких горно-геологических условиях. На особо выбросоопасных пластах при производстве сотрясательного взрывания рекомендуется применять способы снижения интенсивности и частоты выбросов угля и газа. Используется методы увеличения глубины зоны разгрузки призабойной части угольного пласта, которая достигается в шахтных условиях за счет применения способов передового рыхления вмещающих пород, опережающего взрывания, взрывания шпуровых зарядов во вмещающих породах, передового рыхления (камуфлетного взрывания) угольного массива. Кроме того, применяется паспорт БВР с образованием насыпной преграждающей перемычки.

Научная новизна. Сформулированы основные научно-технические принципы безопасного и эффективного использования режима сотрясательного взрывания при выполнении буровзрывных работ на выбросоопасных угольных пластах и породах.

Практическая значимость. Как установлено, использование режима сотрясательного взрывания при ведении горных работ является одним из самых безопасных способов борьбы с газодинамическими явлениями, но одновременно он является, как правило, одним из самых экономически затратных, особенно при необходимости ритмичной работы угольной шахты, поэтому основные направления исследований должны быть продолжены в направлении уменьшения затрат и повышения эффективности применения данного способа.

Ключевые слова: сотрясательное взрывание, режим, проведение выработок, выбросоопасный пласт, безопасность работ

\section{ARTICLE INFO}

Received: 29 March 2016

Accepted: 22 June 2016

Available online: 30 June 2016

\section{ABOUT AUTHORS}

Serhii Mineev, Doctor of Technical Sciences, Head of the Department of Dynamic Phenomena Management of Rock Pressure, Institute of Geotechnical Mechanics named after M.S. Polyakov of the National Academy of Sciences of Ukraine, 2a Simferopolska St, 49005, Dnipropetrovsk, Ukraine. E-mail: sergmineeV@gmail.com

Oleksii Yanzhula, Engineer in Chief, MA "Pokrovske", 1a Shybankova Sq, 85300, Krasnoarmiisk, Ukraine. E-mail: angula@pokrovskoe.com.ua

Oleksii Hulai, Deputy Engineer in Chief, MA "Pokrovske", 1a Shybankova Sq, 85300, Krasnoarmiisk, Ukraine. E-mail: gullay@pokrovskoe.com.ua

Oleksandr Minieiev, Candidate of Technical Sciences, Associate Professor of the Department of System Analysis and Control, National Mining University, 19 Yavornytskoho Ave., 49005, Dnipropetrovsk, Ukraine. E-mail: skulik@i.ua

Valentyna Zabolotnikova, Senior Lecturer of the Department of Foreign Languages, National Mining University, 19 Yavornytskoho Ave., 7/601, 49005, Dnipropetrovsk, Ukraine. E-mail: zabolotnikov@i.ua 